\title{
SEJARAH TARI LULO PADA MASYARAKAT SUKU TOLAKI KELURAHAN ALANGGA KECAMATAN ANDOOLO KABUPATEN KONAWE SELATAN (1800-1996)
}

\author{
Oleh \\ Ahmad Aldin B ${ }^{2}$, Pendais $\mathrm{Hak}^{3}$
}

\begin{abstract}
ABSTRAK: Subtansi penelitian ini mengacu pada tiga aspek permasalahan dasar (1) menjelaskan latar belakang Tari Lulo pada masyarakat Suku Tolaki di Kelurahan Alangga Kecamatan Andoolo Kabupaten Konawe Selatan (1800-1996). (2) Menjelaskan perubahan Tari Lulo pada masyarakat Suku Tolaki Kelurahan Alangga Kecamatan Andoolo Kabupaten Konawe Selatan. (3) Menjelaskan Nilai-nilai yang terkandung dalam Tari Lulo pada masyarakat Suku Tolaki Kelurahan Alangga Kecamatan Andoolo Kabupaten Konawe Selatan (1800-1996). Metode yang digunakan dalam penelitian ini adalah metode penelitian sejarah dengan prosedur mengacu pada Helius Sjamsuddin, yang terbagi tiga tahapan yaitu: (1) Heuristik (pengumpulan data), (2) Kritik sumber (verifikasi data), (3) Historigrafi.

Temuan dari penelitian ini menunjukkan bahwa: 1) Sejarah Tari Lulo pada masyarakat Suku Tolaki di Kelurahan Alangga Kecamatan Andoolo Kabupaten Konawe Selatan merupakan salah satu tradisi masyarakat Suku Tolaki yang memiliki sejrah yang sangat panjang, Berawal dari kegiatan masrakat Suku Tolaki merontokkan bulir padi dari tangkainya, yang disebut "molulowi" kemudian dari gerakan ini, dan rasa persaudaraan dari masyarakat yang sangat tinggi kemudian melahirkan satu karya dalam bentuk tari yang disebut "Lulo"/"Molulo" yang tentunya sangat di sakralkan pada saat itu sebagai satu tradisi sebelum pembukaan lahan pertanian sebagai tempat penanaman padi, atau sesudah panen sebagai bentuk dari rasa syukur masyarakat atas hasil yang di dapat. Penamaan Lulo di adopsi dari bahasa tolaki yaitu kata "Molulowi", dan terbagi dari tiga suku kata Mo-Lulo-Wi, "Mo" merupakan awalan yang berarti mengerjakan sesuatu pekerjaan, "Lulo" berarti menginjak-injak sesuatu sesuatu secara bergantian kiri dan kanan dan kata "Wi" berarti menegaskan suatu pekerjaan pada kata dasarnya. Kegunaan Tari Lulo pada masyarakat Suku Tolaki pada masa lampau yaitu sebagai suatu ritual dalam pembukaan lahan agar dijauhkan dari petaka seperti gangguan makhluk halus dan hama tanaman sekaligus agar penghuni hutan tidak mengganggu baik tanaman atau pemilik lahan, selain itu pada masa lampau Tari Lulo juga digunakan untuk satu ritual pesta panen sebagai bentuk rasa syukur atas hasil yang didapatkan. Nilai-Nilai sosial budaya yang terkandung dalam Tari Lulo adalah: (1) Nilai etika, (2) Nilai solidaritas, (3) Nilai historis.
\end{abstract}

\section{Kata Kunci: Perubahan, Nilai-Nilai, Tari Lulo}

\section{PENDAHULUAN}

Budaya dapat dianggap sebagai identitas suatu bangsa, baik dari ciri khas maupun keunikan dari budaya tersebut. Indonesia merupakan negara yang bukan hanya kaya akan sumber daya alamnya tapi juga negara yang kaya akan kebudayaan, ini terbukti dari banyaknya suku bangsa yang terdapat di NKRI ini, yang merupakan indikasi dari banyaknya pula kebudayaan yang dimiliki oleh bangsa ini. Secara formal budaya di definisikan sebagai tatanan pengetahuan, pengalaman, kepercayaan, nilai, sikap, makna, waktu, hubungan ruang, konsep alam semesta, objek-objek material yang memiliki oleh sekelompok orang dan berkembang dari generasi ke generasi melalui usaha individu ataupun kelompok

\footnotetext{
${ }^{1}$ Disandur dari hasil Penelitian tahu 2019

${ }^{2}$ Alumni Jurusan Pendidikan Sejarah

${ }^{3}$ Dosen FKIP UHO
} 
Faktor yang menyebabkan bersatunya manusia dalam suku-suku, negara, dan sebagainya adalah rasa solidaritas atau hubungan antar masyarakat sebagai hasil peniruan dan pembauran. Faktor tersebutlah yang menyebabkan adanya ikatan dan usaha-usaha bersama yang terjadi antar manusia. Apa yang dikemukakan di atas adalah benar karna pada dasarnya bangsa Indonesia adalah bangsa yang besar dengan tingkat solidaritas yang sangat tinggi, hal ini di buktikan dengan adanya toleransi antar agama yang ada di Indonesia. Selain agama, di Indonesia juga di kenal dengan berbagai macam adat dan budayanya, hal semacam ini tentunya merupakan produk atau karya nyata yang tentunya memiliki nilai luhur yang perlu di manfaatkan dalam kehidupan bermasyarakat, berbangsa dan bernegara dalam membangun bangsa yang kita inginkan.

Dewasa ini kecanggihan-kecanggihan IPTEK mampu meracuni nilai-nilai budaya dari masyarakat, tidak terkecuali dengan "Tari Lulo" yang awalnya, Tari Lulo diiringi dengan alat musik yang biasanya terbuat dari kuningan, umumnya di sebut "gong" dan pada zaman sekarang ini telah berubah dan beralih kemusik-musik pengiring yang lebih modern seperti "orgen"(elekton). Pada dasarnya memang dengan bantuan alat musik modern ini para pelaku Tari Lulo nampak lebih bersemangat, namun di luar dari itu sebenarnya alat musik modern pengiring Tari Lulo ini akan sangat berdampak buruk bagi pendengaran dan pada akhirnya akan merubah bahkan menghilangkan nilai-nilai luhur dari Tari Lulo itu sendiri.

Dari fenomena di atas maka kita dapat mengambil pemahaman bahwa kebudayaan yang ada di Indonesia memang sangat beragam dan tidak sedikit kita akan menemukan kemiripan antara suatu budaya dengan kebudayaan lainnya, atau kemiripan antara satu tradisi dengan satu tradisi lainnya, seperti apa yang ditunjukkan oleh Vosmaer, yang menyatakan bahwa ada kesamaan antara budaya Tolaki dan Dayak yaitu; "koppensnellen" sebuah praktek pemotongan atau memenggal kepala bagi mereka yang dianggap sebagai musuh sebagai sebuah ritual (Vosmaer, 1839: 63). Pernyataan ini dapat dartikan, tidak menutup kemungkinan bahwa budaya suatu daerah akan memiliki kemiripan dengan daerah lain atau bahkan bisa jadi sama. Hal ini karenakan adanya pengaruh-pengaruh budaya luar yang masuk di suatu daerah sehingga dengan proses-proses akulturasi budaya secara perlahan dan memunculkan suatu budaya baru. Contoh lainnya tentang tradisi yang dapat dikatakan mirip dengan Tari Lulo untuk masyarakat Suku Tolaki adalah, tarian daerah yang terdapat di Maluku. Maluku-pun terdapat kebudayaan yang memiliki kemiripan dengan Tari Lulo yang berasal dari Suku Tolaki. Dengan gerakan yang sama namun dengan pola yang berbeda. Ini menunjukkan bahwa kebudayaan khususnya tari adalah kebudayaan bangsa Indonesia yang memiliki keterkaitan antara satu kebudayaan atau tradisi dengan kebudayaan yang lainnya, namun kemudian terjadi perubahan melalui akulturasi budaya dari masyarakat itu sendiri.

Tari Lulo merupakan kebudayaan masyarakat Suku Tolaki yang sekarang sudah menyebar ke segenap daratan Sulawesi Tenggara. Tari Lulo yang notabenenya merupakan hasil kebudayaan dari masyarakat Suku Tolaki, sekarang dapat dengan mudah kita jumpai di mana saja di daerah Sulawesi Tenggara ini khususnya di setiap acara pernikahan, atau pesta-pesta besar lainnya, hal ini di sebabkan karena kebudayaan masyarakat Suku Tolaki ini dapat dengan mudah di pelajari oleh segenap penduduk jazirah Tenggara ini. Tari Lulo adalah hasil kebudayaan yang lahir dari masyarakat Suku Tolaki, yang kemudian berkembang menjadi sebuah tradisi sampai sekarang dan bahkan menjadi pilihan utama perayaan pesta-pesta besar dalam meramaikan acara tersebut, seperti acara pernikahan.

Pada awalnya Tari Lulo adalah sebuah tradisi yang dilakukan untuk sesuatu yang sakral seperti misalnya pada zaman dulu, Tari Lulo ini dilakukan pada hari-hari panen masyarakat Suku Tolaki, atau dengan kata lain Tari Lulo adalah sebuah ritual adat sebagai sesuatu yang harus dilakukan dikala panen telah selesai sebagai suatu bentuk rasa sukur masyarakat Tolaki. Salah satu alasan dan tujuan pelaksanaan upacara tradisional adalah sebagai penguat nilai-nilai dan adat istiadat yang telah ada, dengan demkian upacara adat dapat membangkitkan rasa aman, dan nyaman bagi setiap warga masyarakat dilingkungannya, dan dijadikan pegangan bagi mereka dalam menentukan sikap dan tingkah lakunya sehari-hari.

Tari Lulo ini sendiri telah merambah ke seluruh pelosok jazirah Tenggara, namun dizaman modern ini masih akan kita dapati Tari Lulo tradisional yang dimainkan oleh para orang-orang 
tua/tetua-tetua kampung, baik itu sebagai pembuka suatu acara atau bahkan upacara adat, agar dapat berlangsung dengat hikmat, ataupun lainnya dan tentunya hal ini dilakukan sebagai bentuk kesadaran akan bentuk Lulo kontenporer yang mulai punah, sekaligus mengingtakan kembali para kaula muda akan arti pentingnya Lulo kontenporer baik dari segi makna gerakan ataupun yang lainnya. Hal ini sejalan seperti yang dikemukakan Budiono Herusatoto, (1984: 48), mengemukakan bahwa pelaksanaan upacara adat seharusnya dilaksanakan dengan penuh kesadaran, pemahaman dan penghayatan tinggi yang dianut secara tradisional dari generasi satu kegenerasi berikutnya. Oleh karenanya, upaya mengkaji dan memahami makna dibalik Tari Lulo ini sendiri, perlu dilakukan penelitian mendalam. Zaman sekarang Tari Lulo tidak hanya kita temukan di masyarakat Suku Tolaki, tapi tradisi atau kebudayaan ini akan sangat mudah kita jumpai pada masyarakat suku lainnya dijazirah Tenggara ini. Meskipun demikian, walaupun banyak yang turut serta menjadi pelaku kebudayaan atau tradisi ini, sebagian besar dan bahkan pada umumnya banyak dari mereka yang tidak mengetahui awal kemunculan atau awal terciptanya kebudayaan ini, hingga akhirnya menjadi tradisi bagi masyaraka Suku Tolaki. Masih banyak diantara pelaku kebudayaan ini yang mengesampingkan nila-nilai kesakralan dari budaya ini. Hal ini banyak terjadi di kalangan mudamudi, dimana budaya atau tradisi ini, lebih diperuntukkan atau dimanfaatkan untuk mencari pasangan dan lain sebagainya. Padahal apabila kita melihat jauh kebelakang budaya atau tradisi ini merupaka sesuatu yang sangat di sakralkan oleh para tetua pada masanya.

\section{METODE PENELITIAN}

\section{Jenis dan Pendekatan Penelitian}

Jenis penelitian ini merupakan penelitian sejarah yang bersifat deskriptif dengan menggunakan pendekatan kualitatif. Penelitian deskriptif yaitu jenis penelitian yang bertujuan untuk mendeskripsikan dan menggambarkan secara sistematis tentang sejarah Tari Lulo pada masyarakat Suku Tolaki di Kelurahan Alangga Kecamatan Andoolo Kabupaten Konawe Selatan.

\section{Sumber Data Penelitian}

Sumber data yang digunakan dalam penelitian ini terbagi atas tiga kategori yakni antara lain sebagai berikut; (1) Sumber tertulis, (2) Sumber lisan, dan (3) Sumber visual, keseluruhan data dikumpulkan dari bulan Januari 2019 samapi Maret 2019, dipusatkan di Kelurahan Alangga Kecamatan Andoolo.

\section{Metode Penelitian}

Metode yang digunakan dalam penelitian ini adalah metode penelitian sejarah dengan prosedur mengacu pada Helius Sjamsuddin, yang terbagi tiga tahapan yaitu: (1) Heuristik (pengumpulan data), (2) Kritik sumber (verifikasi data), (3) Historigrafi. penyusunan data merupakan bagian akhir dari seluruh rangkaian penelitian sejarah. Pada bagian ini penulis berusaha melakukan perpaduan kemampuan berpikir dengan kerja seni. Kemampuan berpikir sangat diperlukan pada saat peneliti melakukan kegiatan pengumpulan data terhadap informasi sejarah yang ada, berdasarkan data dan fakta yang berhasil dikumpulkan dan telah lulus verifikasi serta sudah diinterpretasikan.

\section{HASIL PENELITIAN}

\section{Latar Belakang Tari Lulo Pada Masyarakat Suku Tolaki}

Keberadaan Tari Lulo dikalangan masyarakat Tolaki, pada dasarnya tidak lepas dari system pencaharian msyarakat Tolaki kuno. Masyarakat Tolaki kuno dikenal sebagai masyarakat yang nomaden atau dengan kata lain masyarakat yang kehidupannya berpindah-pinda dan kebanyakan masyarakat Suku Tolaki kuno menempati dataran dan pegunungan. Apabilah dilihat 
dari sisi etimology moLulo berasal dari bahasa Tolaki yaitu Molulowi yang artinya merontokan bulir padi dari tangkai padi. Secara umum mo-Lulo berasal dari kata Lulo yang dalam bahasa Tolaki diartikan sebagai menggerak-gerakan atau mengayun-ayunkan kaki kedepan, kebelakang, kekiri, maupun ke kanan. Sedangkan kata Mo dalam kata Mo-Lulowi pada Suku Tolaki merupakan awalan yang berarti mengerjakan suatu pekerjaan sedangkan Wi pada kata Molulowi dalam Suku Tolaki diartikan sebagai akhiran yang menegaskan pekerjaan pada kata dasarnya (Basaula, 2012: 87). Dari penguraian di atas maka jelas bahwa dasar kata Tari Lulo adalah kata Molulowi yang dalam bahasa Tolaki berarti menginjak-nginjak padi atau melepaskan bulir padi dari tangkainya dengan cara di injak-injak.

Dalam versi lain disebutkan bahwa Tari Lulo pada awalnya lahir ketika masyarakat Tolaki kuno akan membuka lahan yang dijadikan sebagai tempat bercocok tanam. Pada saat itu lah masyarakat berkumpul pada lahan baru yang dibuka, lalu mereka meminta pada penguasa alam agar nantinya tanaman mereka tidak diganggu oleh serangan hama dan penyakit. Ketika masyarakat berkumpul maka kepalah suku memberikan perintah untuk membentuk lingkaran, saling bergandengan tangan dan menginjak-injakan kaki yang disertai dengan musik Gong. Kegiatan Molulowi ini memerlukan banyak Palulowi (orang yang merontokan bulir padi dari tangkainya) agar bulir padi dapat terpisah dari batang padi dengan cepat, maka di butuhkan banyak orang untuk kemudian bersama-sama merontokan bulir padi ini dari tangkainya. Awalnya kelompok perontok ini atau di sebut palulowi membutuhkan tempat untuk berpegangan sebagai alat bantu untuk menjaga keseimbangan, namun kemudian media ini tak terpakai lagi, sebagai gantinya agar keseimbangan mereka tetap ada saat berdiri di atas ikatan padi yang akan dirontokkan, maka mereka akan saling berpegangan tangan untuk menyeimbangkan tubuh polulowi, maka dari sinilah awal mula terciptanya tari yang kita kenal seperti sekarang ini, berawal dari rasa persaudaraan yang kuat dari masyarakat Suku Tolaki pada jaman dahulu serta rasa syukur mereka kepada sang pencipta atas rezeki yang telah dilimpahkan terhadap mereka (panen), (Bokoh 6 Maret 2019).

Namun dari sebagian data yang didapat dilapangan banyak pula yang menjelaskan bahwa Tari Lulo diperuntukkan sebagai media penyembahan terhadap dewi padi atau pada masyarakat Suku Tolaki di sebut Sanggoleo Mbae (Basaula, 2012: 87), hal ini dibuktikan oleh beberapa tulisan-tulisan sejarah tentang sejarah masyarakat Tolaki yang banyak menjelaskan tentang kepercayaan yang dianut oleh masyarakat Suku Tolaki yang masih berupa aliran animisme dan dinamisme. Banawula sebagai salah satu narasumber penulis mengemukakan pendapat yang berbeda, yaitu Tari Lulo adalah suatu Tari yang bertujuan sebagai ajang pencarian jodoh, hal ini terbukti baik itu pada zaman sekarang ataupun pada zaman dulu kebanyakan muda mudi menggunakan Lulo sebagai media untuk bertemu dan bersenang, senang dengan lawan jenis "senang-senang dalam artian yang positif", hal ini terekam jelas pada salah satu lagu Tolaki yang berjudul "no peiya Karandu".

Tari Lulo adalah Tari yang berasal dari daerah tenggara pulau Sulawesi dengan berbagai gerakan variasi yang telah banyak diketahui pada zaman sekarang ini. Pada zaman dulu Lulo dikenal sebagai sesuatu yang sangat sakral, betapa tidak, pada zaman dulu masyarakat Suku Tolaki menjadikan Lulo sebagai media penyembahan terhadap Dewi Padi sebagai Dewi kesuburan tanaman padi (Basaula, 2012: 86). Pendapat lain dikemukakan oleh Banawula, ia mengatakan bahwa pada zaman dulu Tari Lulo digunakan sebagai media hiburan bagi masyarakat Tolaki khususnya setelah Panen Padi, Pesta pernikahan, dan acara-acara besar lainnya, bahkan ia mengatakan bahwa pada acara kematian pun dapat dilangsungkan Lulo. Apabila dilihat Dari segi gerakan baik itu Tari Lulo ataupun tradisi lainnya, akan kita dapati kesamaan-kesamaan antara satu tradisi pada suatu daerah dengan tradisi didaerah lainnya. Hal ini sejalan dengan apa yang telah tertulis Dilatar belakang pada bab 1. Telah dijelaskan bahwa ada kesamaan antara budaya Tolaki dan Dayak di yaitu; "koppensnellen", sebuah praktek pemotongan atau memenggal kepala bagi mereka yang dianggap sebagai musuh sebagai sebuah ritual (Vosmaer, 1839:63).

Munculnya Tari Lulo sebagai penyeimbang tradisi Suku Tolaki khususnya dibidang seni, karena awal kemunculan Suku Tolaki yang pada dasarnya masyarakat Suku Tolaki masih memegang teguh hukum adat yang tersemat dalam kalosara sebagai dasar adat Suku Tolaki . 
Dengan kata lain kehadiran Suku Tolaki sebagai suku asli Sulawesi tenggara adalah sebagai pemicu lahirnya hukum adat dalam Kalosara lalu kemudian munculah Tari Lulo sebagai tradisi dibidang seni sekaligus sebagai pemersatu seluruh masyarakat Suku Tolaki. Hal ini tergambar pada salah satu gerakan Tari Lulo yaitu gerakan bergandengan tangan atau yang disebut "Moese" (Abusran, 7 Maret 2019). Telah dikatakan di atas bahwa kemunculan Lulo di awali dengan gerakan Molulowi, pencetus Tarian ini ialah para tetua adat atau biasa disebut juga sebagai pawang padi, namun belum ada sumber baik lisan ataupun tertulis yang mampu menjelaskan secara spesifik siapa orang yang telah berhasil menciptakan Tari Lulo ini. Sebagai bentuk dari pengaktualisasian dari gerakan Molulowi menjadi suatu seni yang mengandung nilai-nilai harmoni, nilai estetika dan nilai adat pemujaan yang bersifat ritual secara melingkar, dan ditengah terdapat lesung padi sebagai pengiring dari Tari Lulo yang kemudian nantinya digantikan oleh Gong yaitu alat musik yang terbuat dari kuningan, dan terakhir pada zaman modern ini telah beralih pada musik listrik yang dikenal sebagai Piano Listrik tunggal (elekton), (basaula, 2012: 87-90).

Penjelasan tersebut kita ambil kesimpulan bahwa bahwa lahirnya Lulo setelah adanya kalosara tepatnya tidak lama setelah masyarakat Tolaki mengenal tanaman padi, karena menurut sebagian sumber Tari Lulo yang tarcipta dari kebiasaan masyarakat Tolaki menginjak-injak padi guna melepas bulir padi dari tangkainya atau yang disebut Molulowi, kemudian dari gerakangerakan inilah sehingga tercipta satu gerakan yang kita kenal sekarang sebagai Lulo. Tari ini awalnya ditujukan sebagai penyembahan pada dewi padi atau pada sumber lain Tari Lulo ini adalah Tari pesta menyambut panen sebagai bentuk terimakasih mereka pada sang pencipta.

\section{Perubahan Tari Lulo pada Masyarakat Tolaki}

Setiap kebudayaan pasti mengalami perubahan dari waktu ke waktu, meskipun tidak begitu cepat namun lambat laun perubahan itu akan terjadi, baik itu perubahan yang disebabkan karena manusia, perkembangan teknologi, maupun karena masuknya budaya baru yang yang dibawah oleh masyarakat pendatang sehingga mengalami percampuran budaya yang pada akhirnya akan mengalami perpaduan antara dua kebudayaan bahkan lebih dari kebudayaan tersebut. Berbicara mengenai perubahan, Tari Lulo juga mengalami perubahan. Perubahan ini dapat dilihat dari dua sisi yaitu sisi alat alat yang digunakan, dan sisi prosesi pelaksanaanya.

\section{Alat Musik Tari Lulo}

Jika ditinjau dari alat yang digunakan maka tampak jelas bahwa alat musik yang digunakan untuk mengiringi Tari Lulo mengalami perubahan. Hal ini dapat dibuktikan dengan memperhatikan secara langsung pelaksanaan Tari Lulo secara langsung dilapangan. Alat yang digunakan untuk mengiringi Tari Lulo dahulu yaitu kanda-kanda wuta (gendang-gendang tanah). Kanda-kanda wuta ini dibuat dengan cara menggali tanah dengan lebar dan dalamnya $40 \mathrm{~cm}$, kemudian ditutup dengan pelepah sagu dan diatasnyalah yang kemudian dipukul-pukul sehingga menghasilkan bunyi. Kemudian seiring dengan berkembangnya waktu tepatnya setelah masuknya islam di Sulawesi Tenggara melalui Syekh Abdul Wahid bin Sayyid Sulaiman yang berhasi mengislamkan Raja Wolio dari Buton pada tahun 1564, kemudian islam masuk di daerah Kerajaan Konawe pada abad ke 18, melalui beberapa tokoh-tokoh yang berhasil mengislamkan Raja Konawe pada saat itu yaitu Lakidende, lalu kemudian Raja Lakidende mulai menyesuaikan adat setempat dengan ajaran islam. Hal ini dibuktikan oleh beberapa bukti sejarah yang ada seperti makam Raja Lakidende sebagai Raja pertama yang dikuburkan menurut ajaran islam sehingga digelari Sangia Ngginoburu atau Raja pertama yang dikuburkan, dalam hal ini dikuburkan menurut tata cara dan ajaran islam.

Masyarakat yang tadinya menggunakan kanda-kanda wuta sebagai alat musik untuk mengiringi Tari Lulo kemudian berkembang dan diubah menjadi Tawa-Tawa, atau masyarakat Suku Tolaki umum menyebutnya dengan sebutan Karandu atau Gong. Dalam banyak sumber menjelaskan bahwa Karandu atau Gong ini adalah satu bentuk alat musik yang dipopulerkan oleh Sunan Bonang di pulau Jawa dan alat Musik ini kemudian menjadi media Sunan Bonang dalam menyebarkan islam di pulau jawa (Basaula, 10 Maret 2019). Oleh sebab itu tidak menutup kemungkinan bahwa Karandu yang dikenal oleh Suku Tolaki sebagai alat musik yang mengiringi Tari Lulo setelah sebelumnya diiringi oleh Kanda-kanda ada pengaruh dari agama islam yang 
dibawa oleh orang Jawa dari pulau Jawa ke Sulawesi Tenggara. Karandu umumnya terbuat dari kuningan, dan alam penggunaannya untuk mengiringi Tari Lulo Biasanya sang-Maistro atau Joki Gong ini menggunakan tiga Gong namun dengan ukuran yang berbeda dan cara memainkannya yaitu dipukul menggunakan dua pemukul yang dirancang khusus seperti stik pemukul druum yang biasa digunakan dikegiatan druum band pada zaman sekarang ini, namun perbedannya adalah pemukul Gong pada zaman dulu terlihat lebih besar dari stik pemukul druum band.

Setelah Gong, kemudian alat musik ini digantikan oleh alat musik listrik yang masyarakat Kelurahan Alangga menyebutnya Tape Dek. Tape Dek adalah Tape Recorder atau umum disebut radio, dalam penggunaannya biasanya masyarakat Suku Tolaki khususnya Kelurahan Alangga juga menggunakan TV sebagai alat bantu untuk penyanyi yang kemudian mengiringi lagu yang dimainkan tape dek pada waktu acara berlangsung. Tape Dek ini muncul sekitaran tahun \pm 1990 1995, (Nurdia, 22 Maret 2019). Umumnya masyrakat yang sudah memiliki Tape Dek ini sudah dikategorikan sebagai "orang kaya" karena sudah memiliki alat musik yang terbilang modern, karena alat musik yang terbilang baru ini pada masa itu sangat jarang dijumpai, selain karena sebagian masyarakat Suku Tolaki yang masih ada keinginan ingin mempertahankan tradisi asli Suku Tolaki yang sudah turun temurun dari nenek moyang sampai pada saat itu, dan juga alasan lain adalah penggunaan alat musik ini yang mengharuskan keberadaan listrik, sedangkan pada masa itu listrik belum samapai di wilayah Kelurahan Alangga, maka sebagai alternatif masyarakat Kelurahan Alangga menggunkan Gengset/Generator sebagai tenaga pembangkit listriknya. Maka hal inilah yang menyebabkan jarangnya dijumpai Tape Dek di Kelurahan Alangga pada masa itu. (Banawula, 9 Maret 2019).

Dizaman Modern ini, alat musik pengiring Tari Lulo telah berganti. Alat musik pengiring Tari Lulo yang digunakan dizaman sekarang ini ialah, alat musik listrik yang umum di sebut Piano Listrik. Piano Listrik/Orgen adalah sebutan dari Bentuk Pertama alat Musik listrik yang berbentuk piano dan digunakan oleh masyarakat Suku Tolaki di Kelurahan Alangga Sekitaran tahun \pm 1995 1996, (Banawula, 9 Maret 2019). Kemudian sekitaran tahun 1996-sekarang masyarakat Suku Tolaki di Kelurahan Alangga menggunakan elekton, (Nurdia, 22 Maret 2019). Elekton adalah jenis Musik listrik sejenis Piano Listrik, namun Lebih Banyak fasilitas di dalam alat tersebut seperti nada yang menyerupai semua alat Musik dengan pengontrol yang berupa tombol dibagian atas alat Musik listrik ini. Elekton ini Dilengkapi dengan banyak spiker yang disimpan di sudut-sudut setiap tempat diberlangsungkannya suatu hajatan. Atas dasar alasan Modernitasi, dan sifat dari Lulo ini sendiri yang terbuka untuk umum maka pengaruh modernisasi dapat dengan mudah menyatu dengan Tari Lulo ini.

\section{Proses Pelaksanaan}

Meskipun dikatakan Tari Lulo dikatakan sebagai tarian rakyat dan diartikan secara massal, namun Tari Lulo ini adalah tari yang memiliki Etika yang mestinya harus tetap berlaku antara lain: a. Cara kita untuk masuk atau bergabung dalam kawanan yang sedang melangsungkan Tari Lulo, tidak boleh dari belakang peserta Lulo (Polulo). Dengan kata lain orang yang ingin bergabung Molulo Harus dari depan tetpai sebelumnya harus meminta permisi terlebih dahulu sebelum memotong lingkaran Polulo, apa lagi sampai memotong tangan Polulo yang berlawanan jenis (laki-perempuan) yang sedang bergandengan, hal ini akan memicu keributan karna dianggap mengambil pasangan dari Polulo tersebut, dan apabila ingin keluar dari lingkaran Lulo, Polulo harus meminta ijin dlu dari pasangannya baik dikiri ataupu disebelah kanannya, dan diwajibkan harus menyelesaikan satu putaran lalu keluar. Namun hal tersebut sudah tidak kita temui lagi dizaman sekarang ini, orang yang ingin ikut serta melaksanakan Lulo seenaknya saja masuk dari belakang, bahkan memotong gandengan tangan pasangan Polulo berlawan jenis, dan keluar dari lingkaran lulo seenaknya saja. Maka tidak jarang kita dapatkan acara Lulo berakhir dengan keributan, dan pada akhirnya akan melukai nilai keindahan dari Tari Lulo itu sendiri.

b. Dalam melangsungkan Tari Lulo kita tidak dianjurkan berbisik-bisikan dengan lawan jenis, dan posisi tangan laki-laki harus berada di bawah tangan perempuan, hal ini ditujukan untuk menghargai posisi perempuan sebagai manusia yang telah melahirkan kita, juga dalam 
pelaksanannya selain lengan tangan bagian bawah yang berayun naik turun tidak di perbolehkan bagian tangan lain ini bertujuan agar tidak terjadi hal-hal yang tidak diinginkan agar tetap terjaga nilai keetisan dalam Tari Lulo. Namun yang terjadi pada zaman sekarang hal-hak sederhana ini sudah hilang, dan tentunya secara otomatis punahlah salah satu nilai sacral dari Tari Lulo.

3. Nilai-nilai Sakral dalam Tari Lulo

Tari Lulo adalah tari yang sangat disakralkan oleh orang-orang tua pada zaman dahulu, hal ini dibuktikan dari tata penggunaannya. Seperti yang sudah disimpulkan sebelumnya bahwa Tari Lulo pada zaman dulu digunakan untuk beberapa hal saja, misalnya ritual pembukaan lahan, ritual pesta panen. Namun dewasa ini seiring dengan perkembangan zaman, Tari Lulo akan dengan mudah kita jumpai di hajatan-hajatan masyarakat Suku Tolaki, namun tidak dengan nilai-nilai yang sebenarnya terkandung dalam Tari Lulo. Tari Lulo adalah Tari yang mengandung Nilai Persaudaraan, Persahabatan, solidaritas, religi, kekeluargaan, seni, dan Moral, serata lainnya, tidak berbeda jauh dengan semua tarian yang ada di bumi Indonesia ini.

Pada perkembangannya Tari Lulo telah banyak memiliki jenis baik dari gerakan, makna ataupun alat musiknya. Pada zaman dulu Lulo terdiri dari tiga jenis:

1. Lulo Sangia; Lulo sangia adalah Lulo yang ditujukan sebagai alat atau media penyembahan bagi masyarakat Suku Tolaki pada dewa-dewi antara lain seperti Dewi Sri, atau dewa-dewi kesuburan lainnya.

2. Lulo Lariangi: Lulo Lariangi adalah Lulo yang pada umumnya masyarakat Tolaki menggunakannya sebagai Tari penyambutan Tamu Terhormat.

3. Tari Lulo MoLulo: Tari Lulo MoLulo ini dapat dkatakan sebagai Lulo yang bersifat bebas, karena dapat dilakukan diberbagai kondisi atau acara, dan sebagian besar pelakunya mudamudi.Maka tidak salah bilah dikatakan Tari Lulo ini sebagai ajang pencarian jodoh. (Basaualah, 2012: 87).

Dalam versi lain Banawula menjelaskan bahwa jenis Tari Lulo tertua hanya terdapat tiga jenis Tari Lulo, namun yang membedakan antara satu jenis Tari Lulo dengan jenis Tari Lulo lainnya hanya terdapat di gerakan kaki. Adapun jenis Lulo yang dimaksud, diantaranya Lulo Biasa, Lulo Moleba, dan Lulo 321. Dan pada perkembangannya kemudian Lulo yang kita ketahui sekarang sudah banyak memiliki jenis-jenis gerakan, dan seperti halnya Lulo tradisional, yang membedakan antara satu jenis Lulo dengan jenis Lulo lainnya di zaman modern ini hanyalah pada gerakan kakinya. Kemudian dalam perkembangannya, di zaman modern ini Lulo Lulo yang terdiri dari beragam jenisnya diantaranya Lulo sangia, Lulo ngganda, Lulo anggo, dan masih banyak lagi.keberagaman ini disebabkan oleh banyak faktor seperti instrumen musik, gerakan dalam Tarian, asal daerah dan bahkan nama penciptanya. Namun, meskipun terdiri dari jenis-jenis yang relatif banyak, prinsip-prinsip dasar gerakan dari Tarian ini adalah sama, yaitu gerak kaki, tangan, dan bentuk lingkaran. Hal yang membedakan antara satu jenis Lulo dengan jenis lainnya adalah fariasi-fariasi gerakannya. Berikut ini beberapa persyaratan umum yang ada dalam Tari Lulo dan sejalan dengan yang dikemukakan oleh Abusran dan Banawula yaitu:

1. Penari-penari bergandengan tangan dan membentuk sebuah lingkaran penuh atau setengah lingkaran. Jika setengah lingkaran, maka yang bertindak sebagai pondombaki (penari paling ujung) harus dari penari laki-laki.

2. Tanga penari laki-laki berada di bawah tangan perempuan posisi tangan tidak rerkait sesuai dengan selera masig-masing.

3. Penari-penari boleh saling bergandengan antara sesama laki-laki, sesama perempuan, atau antara laki-laki dan perempuan.

4. Pada zaman dulu alat musik pengiring Lulo berada di tengah-tengah lingkaran para penari, dizaman modern ini alat musik tradisional yang telah beralih menjadi alat musik listrik kini di tempatkan diluar penari Lulo.

5. Setiap penonton yang masuk menari harus lewat depan dan pada zaman sekarang hal tersebut sudah tidak berlaku lagi dikalangnan muda mudi. 
6. Penari yang akan meninggalkan permainan, harus mundur kebelakang setelah meminta izin dari penari-penari yang mengapitnya.

7. Apabila penonton yang masuk menari dan kebetulan tidak berkenan di hati penari yang akan mengapitnya, maka sangat dilarang untuk meninggalkan tempat seketika itu juga agar tidak terjadi ketersinggungan. Maka sebagai penari lama yang akan mengapit penari baru minimal harus melakukan satu kali putaran lalu meminta izin untuk meninggalkan permainan seorang penari yang baru saja keluar dari barisan tidak diperbolehkan langsung masuk di tempat lain, sebab dapat menimbulkan ketersinggungan dari penari yang ditinggallkan. Ia harus istirahat sejenak kemudian masuk lagi apabila masih ingin meneruskan Tarian.

Selain itu ada beberapa istilah dalam gerak Tari Lulo yang perlu diketahui, yaitu:

1. Moese, artinya gerakan tangan keatas dan kebawah.

2. Molakoako, artinya bergerak kearah kanan dan kearah kiri

3. Nilulo-Lulo, artinya gerakan kaki menginjak-injak. (Maduhali, 10 maret 2019).

Bedasarkan uraian tersebut maka Tari Lulo merupakan salah satu tradisi yang ada di Sulawesi Tenggara yang selalu mengikuti perkembangan zaman. Hal ini dikarenakan sifatnya yang terbuka untuk umum sehingga pengaruh dari luar sangat mudah masuk dan membaur. Sebagai contoh, Musik pengiring dari Tari Lulo ini sudah berganti dua kali dari yang awalnya pengiring Tari Lulo adalah Kanda-Kanda Wuta, kemudian diprediksi karena masuknya islam di Kerajaan Konawe pada abad ke-18 sehingga alat musik sejenis Bonang dari pulau Jawa yang dipopulerkan oleh Sunan Bonang dan di Kendari khususnya masyarakat Suku Tolaki menyebutnya Gong, yang menggantikan kanda-kanda wuta. Kemudian di zaman Modern kemudian Gong digantikan lagi oleh jenis alat Musik listrik yaitu Tape Dek, lalu berganti lagi dngan alat musik listrik lainnya yang dilengkapi dengan spiker, alat Musik ini umum disebut Piano Listrik, dan dizaman sekarangini khusus masyarakat Suku Tolaki menyebutnya Elekton.

Dari segi gerakanpun demikian halnya, Lolu tradisional hanya di kenal beberapa jenis Lulo saja seperti Lulo Sangia, Lulo Lariangi, dan Lulo Molulo. Namun dewasa ini Tari Lulo sdah bermacam-macam jenisnya contohnya Lulo Hada, Lulo Stater, Lulo 321, Lulo Segi Tiga dan masih banyak lagi. Tatacara pelaksanaan Tari Lulo -pun Tidak lagi seperti tata cara pelaksanaan Tari Lulo pada zaman dulu diantaranya bila ingin bergabung dalam rombongan penari, kita diwajibkan untuk masuk lewat depan, tidak boleh berbisik-bisik ketika sedang Molulo, saat Molulo diwajibkan melekukan minimal satu putaran sebelum keluar dari lingkaran Lulo, dan ketika ingin meninggalkan Lulo kita diharuskan untuk berpamitan pada Polulo yang ada dikiiri dan dikanan kita, namun dizaman modern ini dimana para muda mudi kebanyakan sudah tidak lagi ada yang melakukan tata cara pelaksanaan Tari Lulo yang sebenarnya. Hal ini dikarenakan oleh banyak sebab namun yang umum adalah karena faktor ketidaktahuan mereka tata cara pelaksanaan Lulo yang sebenarnya.

\section{Nilai-nilai yang Terkandung Dalam Tari Lulo pada Masyarakat Tolaki}

\section{Nilai Sejarah}

Nilai historis dari Tari Lulo pada masyarakat Suku Tolaki khususnya di Kelurahan Alangga dapat dilihat dari keberadaan Tari Lulo ini sendiri yang tetap terjaga sampai saat ini bahkan mampu menyebar kesegenap penduduk Sulawesi Tenggara, diamana dalam perkembangannya Tari Lulo sudah banyak melewati zaman dengan berbagai macam pengaruhpengaruh luar yang diterimanya namun tetap mampu menyatukan masyarakat Suku Tolaki dalam suatu tempat tertentu, walaupun dengan tujuan yang berbeda.

2. Nilai Solidaritas

Tari Lulo ini juga memiliki nilai Solidaritas hal ini terpampang jelas dari gerakan Moese (gerakan naik turun dengan posisi tangan bergandengan), dan juga Molakoako (gerakan kaki kekanan dan kekiri guna dapat membuat satu putaran lingkaran lulo). Dari dua gerakan ini (Moese dan Molakoako), dapat kita lihat dengan jelas kumpulan orang yang mmbentuk satu lingkaran, bergerak beriringan dan tetap seirama dalam gerakan yang sama. Pada zaman dulu Tari Lulo ini 
E-ISSN: 2502-6674

P-ISSN: 2502-6666

http://ojs.uho.ac.id/index.php/p_sejarah_uho

juga berfungsi untuk ritual adat dalam pembukaan lahan ataupun sesaat setelah panen padi. Dari dua hal ini jelas bahwa Tari Lulo memiliki nilai solidaritas yang sangat tinggi.

3. Nilai Etika

Tari Lulo juga mengandung makna yang bernilai etika, dimana pada zaman dulu etika dari pelaksanaan Tari Lulo ini ialah satu hal yang sangat dijunjung tinggi demi keamanan dari keberlangsungannya suatu acara Lulo, utamanya etika kepada perempuan sebagai makhluk yang telah melahirkan kita kedunia ini, dan juga etika kepada para penari Lulo lainnya yang telah lebih dahulu ada dalam Tarian ataupun yang baru akan ikut masuk bergabung dalam Tari Lulo, karena pada zaman dahulu apabila tata cara pelaksanaan lulo tidak diterapkan dalam hal ini tidak dilakukan, maka hal inilah yang akan memicu keributan.

4. Nilai Estetika

Nilai Estetika atau keindahan dalam Tari Lulo ini terdapat pada gerakan dari Tari Lulo itu sendiri, dan alunan musik yang mengiringi lulo tersebut (Lulo Tradisional). Dimana peraturan dari pelaksanaan Tari Lulo ini yaitu bergerak beriringan dalam satu irama. Dengan kata lain bahwa maestro atau orang yang bertugas memukul atau membunyikan alat musik adalah penentu dari gerakan yang penari mainkan.

\section{KESIMPULAN}

Berdasarkan uraian-uraian yang penulis kemukakan pada pembahasan hasil penelitian di atas, maka penulis dapat menarik kesimpulan sebagai berikut: (1) Tari Lulo lahir dari kebiasaan masyarakat Suku Tolaki pada saat itu merontokkan padi dengan menggunakan kaki yang dalam bahasa Tolaki disebut MoLulowi. Dasar dari kata moLulowi inilah kemudian masyarakat Suku Tolaki menamakan sebuah tari yang dinamakan Lulo. (2) Tari Lulo adalah satu kebudayaan Suku Tolaki yang kemudian menjadi satu tradisi pada masyarakat Suku Tolaki yang pada awalnya Tari Lulo diperuntukkan diberbagai kondisi sesuai dengan kebutuhan pada saat itu. Tari Lulo pada zaman dulu dipergunakan sebagai media pemujaan, Tari Lulo seperti ini biasa digunakan pada acara-acara pembukaan lahan pertama dengan tujuan meminta pada jin-jin penguasa tempat mereka membuka lahan agar tidak mengganggu tanaman para petani, dan juga meminta agar dijauhkan dari hama-hama tanaman. Fungsi lain dari Tari Lulo ini pada zaman dulu adalah sebagai tarian pesta panen, sebagai bentuk ucapan terimakasih kepada tuhan atas rezeki yang diberikan, dan terakhir pada zaman dulu Tari Lulo di jadikan sebagai ajang cari jodoh. Tapi hal ini hanya berlaku pada orang-orang tertentu, dengan kata lain Tari Lulo biasa menjadi sebagai ajang cari jodoh apabila pelaku dari tari ini berniat secara pribadi keacara peaksanaan Lulo untuk mencari jodoh, dan kemudian hal terakhir ini yang bertahan sampai sekarang, yang kemudian ujung-ujungnya akan mengarah kehal-hal yang negative, dan ini jelas akan melumpuhkan arti dari sebuah tari yang pada jaman dahulunya sangat disakralkan oleh masyarakat Suku Tolaki. (3) Dari beberpa penjelasan di atas tentang makna-makna gerakan Lulo, maka jelas ada banyak nilai-nilai yang terkandung dalam Tari Lulo seperti nilai historis diamana dalam perkembangannya Tari Lulo sudah banya melewati zaman dengan berbagai macam pengaruh-pengaruh luar yang di terimanya namun tetap mampu menyatukan masyarakat Suku Tolaki dalam suatu tempat tertentu. Kemudian Tari Lulo ini juga mengandung makna yang bernilai etika, dimana pada zaman dulu etika dari pelaksanaan Tari Lulo ini ialah satu hal yang sangat dijunjung tinggi demi keamanan dari keberlangsungannya suatu acara Lulo, utamanya etika kepada perempuan sebagai makhluk yang telah melahirkan kita kedunia ini, dan juga etika kepada para penari Lulo lainnya yang telah lebih dahulu ada dalam Tarian ataupun yang baru akan ikut masuk bergabung dalam Tari Lulo, karena pada zaman dahulu apabila tata cara pelaksanaan Lulo tidak diterapkan dalam hal ini tidak dilakukan, maka hal inilah yang akan memicu keributan. Terakhir, Tari Lulo juga memiliki nilai Solidaritas hal ini terpampang jelas dari gerakan Moese (gerakan naik turun dengan posisi tangan bergandengan), dan juga Molakoako (gerakan kaki kekanan dan kekiri guna dapat membuat satu putaran lingkaran Lulo). (4) Tari Lulo adalah tari tradisional yang sangat menggambarkan semua sisi kehidupan masyarakat Suku Tolaki. Oleh karenanya Tari Lulo adalah sesuatu yang dapat dikatakan sebagai, Pusat Gerak Kehidupan Masyarakat Suku Tolaki. 
Jurnal Penelitian Pendidikan Sejarah

E-ISSN: 2502-6674

P-ISSN: 2502-6666

http://ojs.uho.ac.id/index.php/p_sejarah_uho

\section{DAFTAR PUSTAKA}

Ambary, 1998.Jejak Arkeologis dan historis Islam di Indonesia. Jakarta: Logos PT. Wacana Ilmu. Basrin Melamba, dkk, 2011. Sejarah Tolaki di Konawe. Yogyakarta: Teras.

Braudel, 1996. The Mediteranian and the Mediteranean World in the Age of Philiip II. Jilid 2: New York.

Bintarto, 1980. Gotong Royong Suatu Karakteristik Budaya Indonesia.Surabaya: Bina Ilmu.

C Kluckhon, 1951.Cultur and Behavior. New York: The Free Press.

Djoko Widagdo, dkk. 2003. Ilmu Budaya Dasar. Jakarta: Bumi Aksara.

Helius Sjamsudin, 2012. Metodologi Sejarah. Yogyakarta: Ombak.Herman, 2005. Nilai Kehidupan dalam Cerita Rakyat Masyarakat

Hugiono, 1987. Pengantar Ilmu Sejarah. Jakarta: PT. Bina Aksara.

John Lecthe, 2001. 50 Filsuf Kontemporer. Yogyakarta: Kanisius.

Koentjaraningrat, 1983.Kebudayaan Mentalitas dan Pembangunan. Jakarta: Gramedia.

Muhammad Arif, 2011. Pengantar Kajian Sejarah. Bandung: Yrama Widya.

Moh. Ali, 2005. Pengantar Ilmu Sejarah Indonesia. Yogyakarta: PT LKiS Pelangi Aksara.

Muliono, 2017. Sejarah Benteng Togo Molengo di Pulau Kapota Kecamatan Wangi-Wangi Selatan Kabupaten Wakatobi. Skripsi. Kendari: FKIP UHO.

Nugroho Notosusanto, 1978. Masalah Penelitian Sejarah Kontemporer. Jakarta: Yayasan Idayu Press.

Poesponegoro, dkk, 2010. Sejarah Nasional Indonesia III. Jakarta: Balai Pustaka.

Rene Van Der Berg, 1996. Kamus Muna-Indonesia. Kupang: Artha Wacana.

Roger M. Keesing, 1989. Antropologi Budaya Jilid I. Jakarta: Erlangga.

Sarita Pawiloi, 1989. Sejarah Nasional Indonesia I. Jakarta: Universitas Indonesia Press.

Sartono Kartodirdjo, 1993. Sejarah Pergerakan Nasional. Jakarta: Gramedia Pustaka Utama.

Van Peursen, 1985. Strategi Kebudayaan. Jakarta: Balai Pustaka. 